\title{
中性線電流分離合成法による無効電力補償
}

$\begin{array}{llllll}\text { 学生員 } & \text { 村 } & \text { 瀬 } & & \text { 剛 } & \text { (東京工芸大学) } \\ \text { 学生員 } & \text { 戸 } & \text { 賀 } & \text { 澤 } & \text { 智 } & \text { (東京工芸大学) } \\ \text { 正員 } & \text { 中 } & \text { 野 } & \text { 博 } & \text { 民 } & \text { (東京工芸大学) } \\ \text { 正員 } & \text { 難 } & \text { 波 } & \text { 江 } & \text { 章 } & \text { (東京工芸大学) }\end{array}$

Reactive Power Compensation based on Neutral Line Current Separating and Combining Method

Tsuyoshi Murase,Student Member,Satoshi Togasawa,Student Member

Hirotami Nakano,Member,Akira Nabae,Member (Tokyo Institute of Polytechnics)

キーワード：無効電力補偵、三次元クロスベクトル、三相四線式系統、中性線電流分離合成法

\section{1. 緒諞}

先に筆者らは、三相三線系統の瞬時無効電力補償装置に クロスベクトル理論を適用することにより、その制御シス テムが極めてシンプルになることを示した。(3)(4)

しかしながら、三相四線式系統へクロスベクトル理論を 単に適用すると、制御システムのシンブル化が効果的でな いという問題があった。(4)

そこで、本論文では、三相四線式系統へのクロスベクト ル理論の適用法として、中性線電流分離合成法を提案する。 それにより、三相三線式系統の場合と同様に、制御システ ムのシンブル化が效果的に計れることを理論的に示し、実 験によりその有用性を検証する。

\section{2. 中性線電流分盽合成法}

無効電力に奇与する瞬時無効電流空間ベタトル1ょの一 般式は、瞬時電圧空間べクトルe $(e=e, x+e 、 y+$ e $w \mathbb{Z})$ 上瞬時電流空間ベクトルi $(i=i 、 x+i 、 y$ 十1、z）とのベクトル積である三次元クロスベクトルC により次式で表わされる。(4)

$$
i_{\perp}=\frac{\mathbb{C} \times \mathbb{e}}{e \cdot e}
$$

（1）式を、各相の成分で表わすと次式になる。

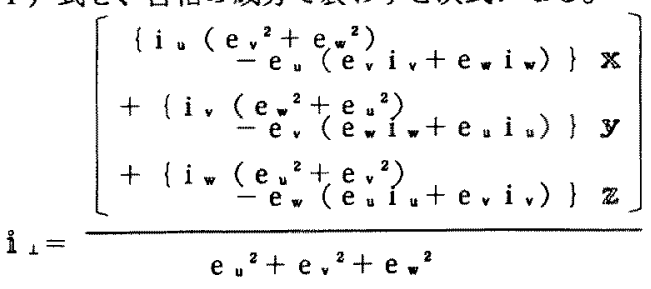

三相四線式系統においては、三相各相の電压の和は零で あるが、電流の和が零でない( $\left.i_{u}+i_{v}+i_{v} \neq 0\right)$ 場
合には、各相の電流には中性線電流成分が含まれる。その 為、（2）式を簡略することは困難である。

そこで、まず各相の電流より中性線電流成分を分離させ、 分離後の各相の電流を用いて三相三線式の瞬時無効電流検 出回路で各相の三相三線式の瞬時無効電流を検出する。そ して、その検出された各相の電流に中性線電流成分を合成 して、三相四線式の瞬時無効電流を得る。その原理図を図 1 に示す。

(2) 式に上記の方法を適用すると、以下のようになる。 中性線電流成分をi。とすると各相の電流は、次式となる。

$$
i_{u}=i_{u}+i_{n}, i_{v}=i_{v}+i_{a}, i_{w}=i_{w}+i_{n}
$$$$
\text { (但し、 } i_{a}^{*}+i_{*}^{*}+i *=0 \text { である。) }
$$

ここで、上式を（2）式に代入すると次式となる。

$$
\begin{aligned}
& \left(e_{u} i_{v}-e_{v} i_{u}\right) \\
& \times\left(e_{w}-e_{v}\right) x \\
& \left.+\left(e_{u}-e_{w}\right) y+\left(e_{v}-e_{u}\right) z\right\}
\end{aligned}
$$

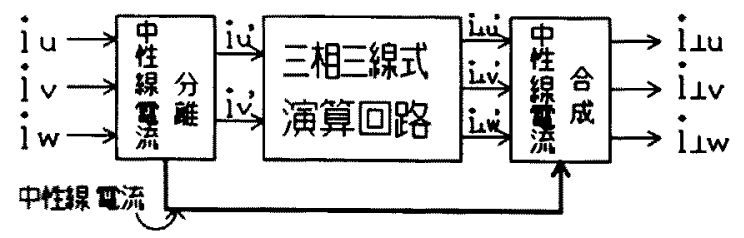

図 1 中性線電流分離合成法原理図

Fig. 1. Neutral Line Current Separating and Combining Method

\section{3. 䁌時無効電流模出回路}

図 2 は、（3）式に基づいた瞬時無効電流検出回路であ る。同図の点線内は、同式の第 1 項に基づき構成されてい 


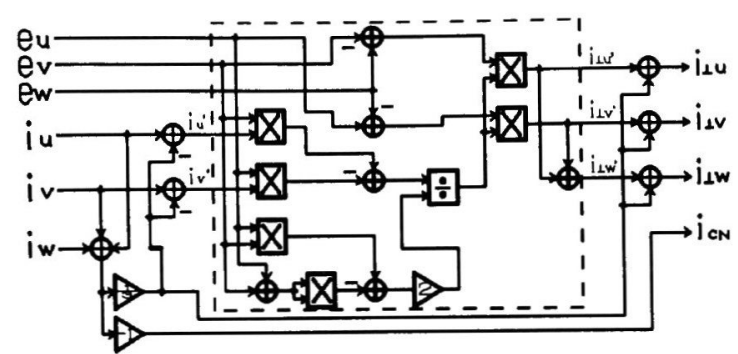

図 2 瞬時無効電流演算ブロック図

Fig. 2. Block Diagram of detecting circuit

ろ三相三線式の瞬時無効電流検出回路であり、また、 $\mathrm{i}_{\mathrm{cN}}$ は中性線電流を示す。

\section{4. 実験のシステム構成と結果}

図 3 に瞬時無効電力補償装置の主回路構成を、図 4 に三 相半波整流回路を負荷とした過渡状態での実験結果を示す。

図4より、過度状態であっても瞬時力率は常に 1 で、補 償後の系統電流は、ほぼ正弦波状の良好な結果が得られて いることが分る。

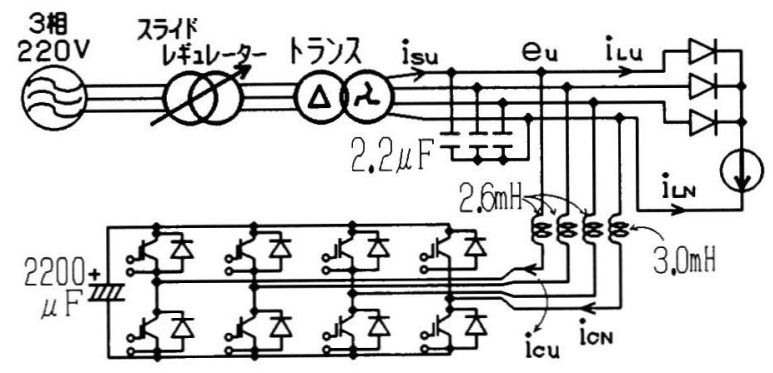

図 3 瞬時無効電力補償装置の主回路

Fig. 3. Main Curcuit of the instantaneous reactive power compensator
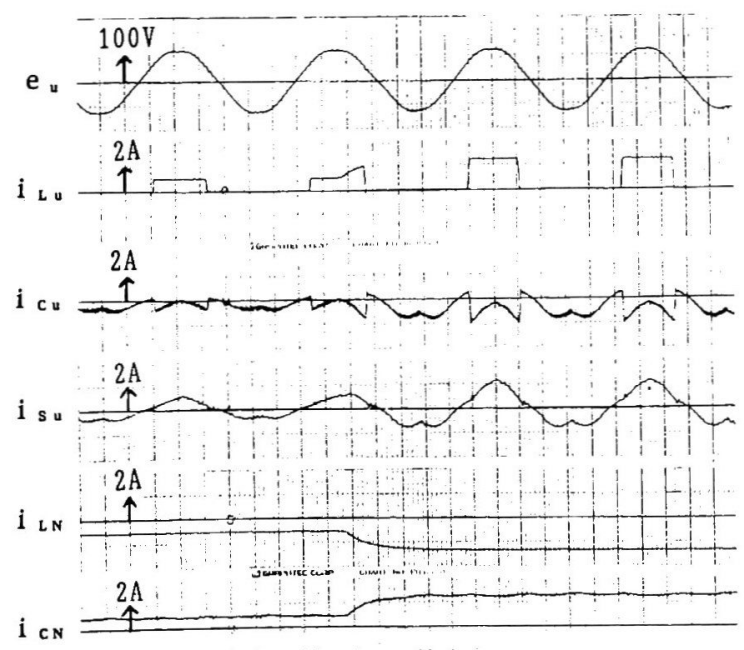

図 4 実験結果

Fig. 4. Experimental result

\section{5. 耛諭}

本論文では、三相四線式系統における瞬時の無効電力補 償を行うにあたり、クロスベクトル理論の拡張として中性 線電流分離合成法なるるのを用い、これにより非常にシン プルな制御システムが得られたことを、理論と実験により 検証した。

(平成 6 年 2 月 25 日受付)

文献

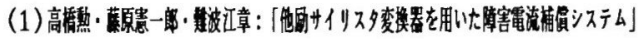

電学新B. 101 (敗56-3)

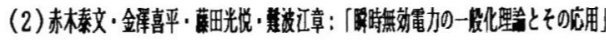

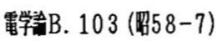

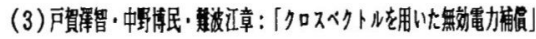

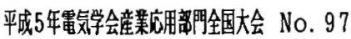

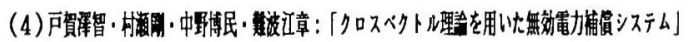

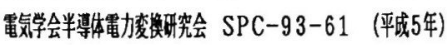

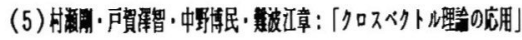

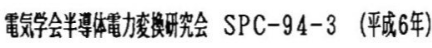

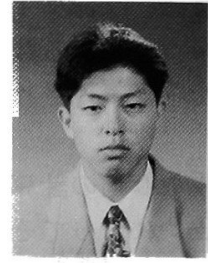

村瀬 剛 (学生員)

昭和 46 年 10 月 7 日生。平成 2 年北海道道 立帯広三条高等学校卒業。同年 4 月東京工 芸大学工学部電子工学科入学。現在に至る。

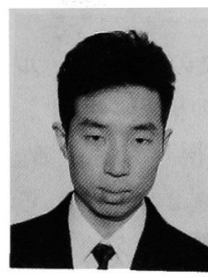

戸賀澤 智 （学生員）

昭和 46 年 1 月 8 日生。平成 5 年 3 月東京 工芸大学工学部電子工学科卒業。同年 4 月 同大学大学院工学研究科電子工学専攻修士 課程入学。現在に至る。

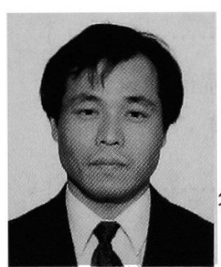

中野 博民（正員）

昭和 32 年 7 月 31 日生。同 55 年 3 月長岡技 術科学大学電子機器工学課程卒業。同 57 年 3 月同大学院工学研究科修了。同 62 年 3 月 名古屋大学大学院工学研究科博士課程修了。 平成 5 年東京工芸大学助手。工学博士。 半導体電力変換器、無効電力補償システムの研究に従事。

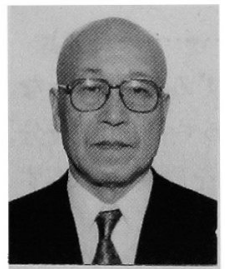

難波江 章 (正員)

大正13年 9 月 13 日生。昭和 22 年 9 月東京 大学電気工学科卒業。同 26 年 9 月(侏東芝入 社。同58年 4 月長岡技術科学大学教授。平 成 2 年東京工芸大学教授。工学博士。 IEE Fellow。昭和 60 年、平成 3 年電気学 会論文賞。'91IEEE-IAS Tr. Paper Award。平成 5 年電気学 会業績賞。 